\title{
The contribution of 'chitoumou', the edible caterpillar Cirina butyrospermi, to the food security of smallholder farmers in southwestern Burkina Faso
}

\author{
Charlotte L. R. Payne ${ }^{1}$ (D) Athanase Badolo ${ }^{2} \cdot$ Sioned Cox ${ }^{3} \cdot$ Bakary Sagnon $^{2} \cdot$ Darja Dobermann $^{4}$. \\ Charlotte Milbank $^{5} \cdot$ Pete Scarborough $^{6} \cdot$ Antoine Sanon $^{2} \cdot$ Fernand Bationo $^{7} \cdot$ Andrew Balmford $^{1}$
}

Received: 15 March 2019 / Accepted: 20 November 2019/Published online: 6 December 2019

(C) The Author(s) 2019

\begin{abstract}
Edible insects have been advocated as a means to combat food insecurity, which is prevalent in West Africa. In this study we look at the contribution of the shea caterpillar Cirina butyrospermi, colloquially known as 'chitoumou', to the food security of smallholder households in rural southwestern Burkina Faso. We used a mixed methods approach to understand the relationship between caterpillar collection, consumption, and sale by smallholder households, and their seasonal food security status. We found that caterpillars are an important source of food and income for households, significantly increasing the household consumption of animal protein and, with shea nuts, representing the main income source for the majority of women. We also found that food security is higher during caterpillar season, and that household-level food security during this season can be predicted by the amount of caterpillars collected, consumed and sold. However, this relationship holds only during the caterpillar season, suggesting that the positive impact of caterpillars on food security is temporally limited. We conclude that the shea caterpillar is an example of an edible insect that is crucial for seasonal food security in a widespread agricultural system.
\end{abstract}

Keywords Edible insects $\cdot$ Smallholder farmers $\cdot$ Burkina Faso $\cdot$ Nutrition $\cdot$ Food security $\cdot$ Livelihoods

Electronic supplementary material The online version of this article (https://doi.org/10.1007/s12571-019-00994-z) contains supplementary material, which is available to authorized users.

Charlotte L. R. Payne

charlotte.payne@gmail.com

1 Conservation Science Group, Department of Zoology, University of Cambridge, Cambridge, UK

2 Laboratoire d'Entomologie Fondamentale et Appliquée, Université Ouaga 1 JKZ, 03 BP 7021, Ouagadougou, Burkina Faso

3 Department of Archaeology, University of Cambridge, Cambridge, UK

4 Rothamsted Research, Harpenden, UK

5 Department of Geography, University of Cambridge, Cambridge, UK

6 Nuffield Department of Population Health, University of Oxford, Oxford, UK

7 Département de Sociologie, Université Ouaga 1 JKZ, 03 BP 7021, Ouagadougou, Burkina Faso

\section{Introduction}

Food insecurity disproportionately affects those who produce the majority of the world's food: over half of all food calories are produced by rural smallholder farmers, who live in the Global South (Samberg et al. 2016) and are disproportionately likely to be food-insecure (Sibhatu and Qaim 2017). The reasons behind this are complex. At the FAO World Food Summit in 1996, food security was defined as a situation in which 'all people, at all times, have physical and economic access to sufficient, safe, and nutritious food to meet their dietary needs and food preferences for an active and healthy life'. Several definitions since have also focused on the importance of access, particularly in the context of unpredictable and fluctuating world markets (Porter et al. 2014).

Given the importance of financial markets, perhaps it is no wonder that it is the producers themselves who suffer disproportionately from food insecurity. However, the relationship between economic growth and increased food security is complex and variable, and may depend on the nature of government policies concerning food and development (Timmer 
2005). The FAO advocates that economic growth can only promote food security in the context of sustainable livelihood opportunities that are inclusive of the rural poor and augment both income and food production (FAO 2015). Dietary quality is also a key element of food security, although consensus about what constitutes a nutritionally adequate diet fluctuates (Semba 2016). The emphasis is not on food insecurity being due to a lack of food per se, although this is the case for approximately 821 million people (WHO 2018). More prevalent today is 'hidden hunger', which affects over 2 billion people globally and refers not to caloric deficiency but to a lack of adequate micronutrients (IFP 2014).

Strategies to tackle food insecurity among rural smallholders have included those that are 'food-based', such as supplementation (Burchi et al. 2011), as well as those that focus on improving livelihoods (Garibaldi et al. 2017). Yet ultimately, food insecurity cannot be reduced to either component part. Food sovereignty (Weiler et al. 2014), education (Kaiser et al. 2015) and empowerment of women and minority groups (Conceição et al. 2016) also play key roles in improving food security. Thus, food security has multiple dimensions that include the social, the cultural and the political.

Edible insects have been highlighted as a means of combating these different aspects of food insecurity: many insects are high in protein and micronutrients, are often collected by women and minority groups, and can improve the livelihoods of rural smallholders able to harvest them (Van Huis et al. 2013). Many edible insects are harvested from wild land, but others are found within agricultural systems and can be a valuable source of both nutrition and income for farmers (Payne and Van Itterbeeck 2017). Previous studies have shown that insects make a significant contribution to food security (Manditsera et al. 2019; Baiyegunhi et al. 2016), but many unanswered questions remain about whether this is due to their contribution to income or to household meals, and also how much this benefit extends beyond the time when insects are seasonally available.

In West Africa, food insecurity is a significant problem. An estimated 56.1 millon people are undernourished and $38 \%$ of children are wasted or stunted (WHO 2018). There is some evidence to suggest that this may be due to increasing yield deficits due to climatic change, which have been cited as one cause for increased southward migration to escape desertified, unproductive soils (WHO 2018; Ritzema et al. 2017). Regardless of the driving forces behind such movement, in many regions population density is increasing as a result, and this rise in population pressure is contributing to environmental degradation (Douxchamps et al. 2016).

Insects are enjoyed as food in many parts of West Africa, where important species include locusts, palm weevil larvae and caterpillars (Anankware et al. 2016; Anvo et al. 2016; Agbidye et al. 2009; Banjo et al. 2006; Tchibozo et al. 2005). Edible caterpillars play an important role in food security throughout Africa as a food that is harvested from forest, savannah and other uncultivated land (Yen 2015; Malaisse et al. 2017). However, in the shea belt - a cultivated region, spanning 21 countries from Uganda and Sudan in the east to Guinea in the west and dominated by the shea tree Vitellaria paradoxa (Naughton et al. 2015) - the shea caterpillar (Cirina butyrospermi) is collected in agricultural fields and is a significant part of the wider agricultural system. The caterpillar is colloquially known as 'chitoumou'. This is pronounced ' $f i-t u m u$ ': ' $f i$ ' means 'shea', and 'tumu' means 'caterpillar'; this nomenclature is used by multiple ethnic groups including persons of all ethnicities who participated in the current study. It feeds exclusively on the leaves of the shea tree and when in season, is ubiquitous at rural and urban markets and trading posts. Prior research has shown that shea caterpillars are high in protein, fat and minerals (Anvo et al. 2016), and that diets containing shea caterpillars are higher in protein and zinc, two essential nutrients for combatting nutritional deficiencies in this region (Cox et al. 2018). Attempts to rear shea caterpillars in enclosed systems has thus far succeeded in breaking their 9-month diapause, but methods for commercial-scale rearing have not yet been developed (Bama et al. 2018; Rémy et al. 2017). Attempts to include caterpillars in fishmeal using proportions of up to $50 \%$ have also been successful, although they are not currently used as commercial feed (Anvo et al. 2017).

The aim of this study is to understand the role of the shea caterpillar in relation to food security in the shea belt region of West Africa. We ask how caterpillars compare to other sources of nutrition and income in rural southwestern Burkina Faso, and we investigate the nutritional and financial contribution of caterpillars to households that collect them. We use household interview data to ask whether the seasonal abundance of caterpillars has a measurable impact on food security among rural populations in this region, and look at the extent and nature of this impact on households that collect caterpillars. Finally, we consider whether ethnicity, location and household wealth predict the quantities of caterpillars consumed and sold.

\section{Materials and methods}

\subsection{Sampling strategy and study design}

We collected data on a random stratified sample of 25 households (stratified by household size) out of 50 in the SoumossoKoba-Larama area of southwestern Burkina Faso (Fig. 1) which cultivated $>1$ ha of land and collected caterpillars. That is, we used a list of 50 households collected using snowball sampling on our pilot field trip, stratified this list by household size - the number of individuals living in a household - and used a random number generator to select a 
Fig. 1 Map showing of main study areas in Burkina Faso: Sitiena $\left(10^{\circ} 36^{\prime} 19.5^{\prime \prime},-004^{\circ} 49^{\prime}\right.$ 03.3"), and the Soumosso-KobaLarama area, comprising Soumosso $\left(11^{\circ} 00^{\prime} 44.2^{\prime \prime}\right.$, $\left.-004^{\circ} 02^{\prime} 45.8^{\prime \prime}\right)$, Koba $\left(11^{\circ} 00^{\prime}\right.$ $\left.52.1^{\prime \prime},-003^{\circ} 59^{\prime} 42.2\right)$, and Larama $\left(11^{\circ} 03^{\prime} 02^{\prime \prime},-004^{\circ} 00^{\prime}\right.$ $\left.02.3^{\prime \prime}\right)$

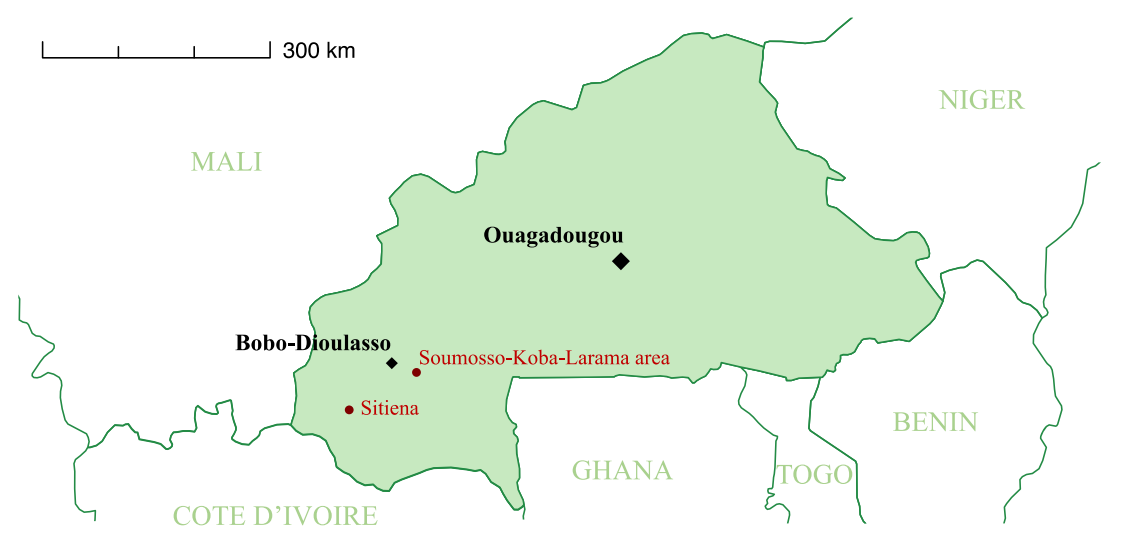

subsample of $N=25$ within each strata. In this region, land is owned by the chief; residents ask the chief for land that they can then cultivate as they see fit. Shea trees are ubiquitous across cropland and are also very common in forests and fallow areas. Shea fruits and nuts are harvested by the person who manages the land, and are not a communal resource. During our pilot study and during 15 months of fieldwork we did not come across nor hear of a single household that does not have at least one member who collects caterpillars, and we only knew of one household that did not cultivate any land: therefore we believe that the demographic of our sample is as representative of this region as was feasible in the bounds of the current study.

The sample of $N=25$ households in Soumosso represents households whose male head of household is one of three ethnicities $(N=11$ Diioula, $\mathrm{N}=11$ Mossi, $N=3$ Bobo). The median asset base was 3,000,000CFA (range $=1,460,000 \mathrm{CFA}$ to $10,200,000$ CFA).

We identified, by snowball sampling, 20 households in the Sitiena area $(95 \mathrm{~km}$ southwest) that met the same criteria, but we were not able to take a stratified sample due to time constraints. This sample represents Karaboro$(N=15)$ and Gbin-headed $(N=5)$ households. The female head of household (first wife of the male head of household) in each of the resulting 45 households formed the core sample of women for all structured interviews and Household Food Insecurity Access Score (HFIAS) surveys (Coates et al. 2007). Men, women and children all collect caterpillars, and the prevalent method of collection is to harvest them from the ground before sunrise, as described in Cox et al. (2018). We chose to interview only women because we had found from pilot surveys that they hold the primary responsibility for preparing meals for the household, and for collecting wild foods. We also found that women are responsible for purchasing food for the household, and that they keep the money from the caterpillars that they collect. Looking at the financial benefits of caterpillars to the men and children in households in this region is beyond the scope of this study.
We used a mixed methods approach to give greater voice and agency to research participants, and to recognise the importance of multiple perspectives (Green and Thorogood 2014). We use qualitative data to complement, triangulate and challenge the results generated by quantitative methods (Creswell and Clark 2007). Our quantitative methods of data collection are structured interviews, $24 \mathrm{~h}$ recall surveys, nutritional analyses and HFIAS surveys; our qualitative methods are group interviews and participant observation.

\subsection{Structured interviews}

We conducted structured interviews with women from our core sample during July-September 2016 and 2017, up to two months after each year's caterpillar season. Questions covered the quantity of caterpillars and shea collected, eaten, sold and given away by the household, the time spent and money gained for each harvest, the money gained from the harvest and sale of shea nuts, and the assets of the household.

To estimate household wealth, we summed the market values of all assets (livestock, forms of transport, and land) for each household. Market values were as follows: cow 175000CFA, sheep 27500CFA, goat 25000CFA, chicken 2000CFA, guinea fowl 3000CFA, donkey 80000CFA, bike 20000CFA, motorbike 800,000 , land per ha 350000 CFA. These values were ascertained from three key informants on separate occasions and we took a mean value in the case of discrepancies.

\subsection{The caterpillar season}

The 'caterpillar season', as used in this study, is a literal translation of the term used locally, chitoumou wakati, in Dioula (chitoumou $=$ shea caterpillar; wakati $=$ time period). is used to refer to the time of year when people are collecting, eating and selling fresh caterpillars. We asked respondents to estimate the number of days that they had collected caterpillars during the past season. 
Even within the same village, areas differ as to the exact timing of the caterpillar season. The timing also varies by year. All data on the collection and sale of fresh caterpillars were obtained in July and August 2016 and 2017. Fresh caterpillars, which weigh a few grams and are pictured with a child's hand for scale in Fig. 2, are usually boiled with salt and potash, then friend or boiled further with seasonings. Caterpillars may be sun-dried and conserved for sale or consumption at a later date. Duration of safe conservation seems to differ according to the circumstances in which they are kept; they can reportedly last 3-6 months when dried. They are then reconstituted using boiling water before cooking. We record this as 'consumed dry'.

\section{$2.424 \mathrm{~h}$ recall surveys}

We conducted dietary interviews following the $24 \mathrm{~h}$ recall method (Biro et al. 2002) with 16 respondents, who represented a stratified subsample of those women interviewed for the HFIAS surveys (with four respondents from each HFIAS category). We asked respondents to recall all foods and drinks that they (individually) had consumed during the previous $24 \mathrm{~h}$, and to estimate portion sizes. Average interview length was $25 \mathrm{~min}$, and we conducted all interviews in the morning to aid recall (Huybregts et al. 2009). To maximise accuracy of recall we used the multiple pass method (Wrieden et al. 2003): for the first pass respondents recalled all foods and beverages consumed during the previous twenty-four hours; for the second pass respondents identified when and where foods were consumed; for the third pass we recalled the report to the respondent to prompt for any forgotten items. Finally we reviewed, and confirmed with the respondent, all items recorded. Interview questions were conducted in the respondent's first language, with the assistance of trained field assistants. We used household measures to aid estimates of portion size, and retrospectively converted these to grams using 'FAO/INFOODS Density Database Version 2.0' (Charrondiere et al. 2012a). We matched food items with energy and nutritional compositional values from the West African Food Composition Table (Charrondiere et al. 2012b). When an exact match was not possible, food items

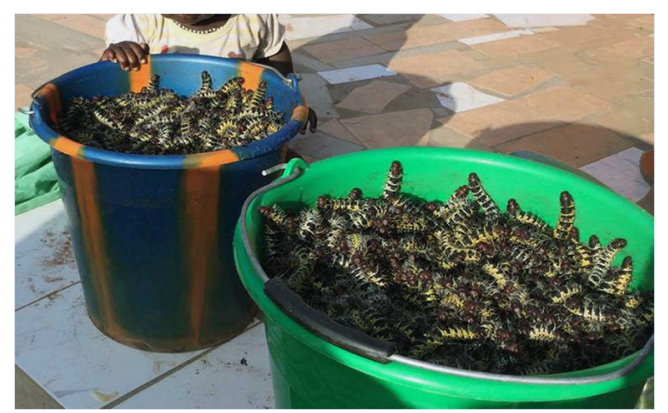

Fig. $211 \mathrm{~kg}$ of live final instar caterpillar larvae, freshly collected and ready for cooking, pictured with the hand of a two-year-old child for scale were matched with values available from other published sources available (Anvo et al. 2016; Greffeuille et al. 2010; Nordeide et al. 1996); if these were unavailable we used the mean of the values for several similar items (in accordance with the 'INFOODS Guidelines for Food Matching' Stadlmayr et al. 2011). When analysing the data, we found that for $N=3$ reported dishes the portion reported exceeded $200 \%$ of a person's daily Kcal intake; we excluded these dishes from our final analysis.

\subsection{Nutritional analysis}

Wild insects vary widely in their micronutrient composition, depending on the species and their life stage, and also on the habitat and soil composition at their geographical origin (Payne et al. 2015). To determine the average micronutrient content of the caterpillars in this region we collected samples of 3 final-instar individuals from each of 9 fields stratified by distance from the road to ensure that soil type represented the range of soil types from which caterpillars are collected in the study area. We chose to use final-instar caterpillars because this is the life stage at which they are traditionally collected. After weighing the caterpillars we prepared them as they are usually prepared for sale: we boiled them with potassium and dried them in the sun.

Micronutrient analyses were carried out at Rothamsted Research, UK. We placed $500 \mathrm{mg}$ of each caterpillar sample in $25 \mathrm{ml}$ graduated digestion test tubes, with one sample out of every three repeated to check analysis accuracy. Two wheat flour samples were included as a certified standard and two blank control tubes to establish any potential contamination in the solvents. Samples were pre-digested in $5 \mathrm{ml}$ of 15:85 nitric:perchloric acid (HNO3:HClO4) for $5 \mathrm{~h}$ then heated overnight to $175{ }^{\circ} \mathrm{C}$ to evaporate the acid. $5 \mathrm{ml}$ of $25 \%$ HNO3 was added and the tubes heated to $80{ }^{\circ} \mathrm{C}$ for $60 \mathrm{~min}$. Samples were made up to a final volume of $25 \mathrm{ml}$ with ultrapure water, decanted and analysed using an Optima Inductively Coupled Plasma - Optical Emission Spectrometer (ICP-OES) (Zhao, McGrath, \& Crosland, 1994). All Nitric acid was Aristar grade.

\subsection{HFIAS surveys}

To measure perceptions of household food security during and outside of caterpillar season, we chose the HFIAS due to its sensitivity to food access, quantity and reported anxiety, its applicability to measuring food security at household level (Jones et al. 2013), and its use in similar settings (Baiyegunhi et al. 2016). We refined the questions for use in the Soumosso-Koba-Larama area with five local bilingual key informants to ensure that translated questions were accurate and contextually appropriate (following Coates et al. 2007). Three of these key informants acted as translators to assist 
with data collection, with at least one present at every HFIAS interview. We first selected survey respondents from our core sample, and then sought further respondents via snowball sampling (Heckathorn 2011) to expand our sample size. We conducted 59 HFIAS interviews with women outside of caterpillar season (during the dry season, in March 2017), and repeated 57 of these during caterpillar season (July 2017). In seven of our 59 cases, it was not possible to repeat the interview with the same woman, due to death $(N=2)$, ill health $(N=1)$ or absence from the village $(N=4)$ but in five of these instances we interviewed another woman in the same household in her place; in the two remaining instances we were not able to identify a meaningful replacement. We calculated all HFIAS metrics reported here from these repeat caterpillar- and dry-season interviews $(N=57)$, following Jones et al. (2013). We calculated the HFIAS score (from 1 to 27) and HFIAS category (from 1 to 4 ).

\subsection{Post-HFIAS surveys}

We also asked HFIAS survey respondents about protein consumption in the past month to further understand the nutritional role of shea caterpillars in relation to other protein sources. Specifically, we asked respondents to estimate the number of times in the past month that they had consumed meat ('sogo', which includes poultry, ruminants and wild game), fish ('jige') and shea caterpillars ('chitoumou'). All results reported here reflect the responses of the $N=57$ women who participated in HFIAS surveys in both seasons.

\subsection{Group interviews}

In order to validate and expand on quantitative data gathered via structured interview and participant observation, we followed a triangulation approach to mixed methods (Creswell and Clark 2007) and conducted 9 group interviews in January 2018, during the dry season (which is approximately January-April each year). We held group interviews in the Koba $(N=6)$ and Larama $(N=9)$ localities (Fig. 1). Following previous experience conducting group interviews here we limited our group interviews to include $2-3$ women in each. The first participant for each was selected at random; others were selected according to ethnicity/language (matching the ethnicity/language of the first participant) and/or geographic proximity and availability. In total, 20 women, ranging in age from 18 to $60 \mathrm{yrs}$. (mean age $38.4 \mathrm{yrs)}$ ) and representing three ethnicities (Dioula $=8$, Mossi $=6$, Bobo $=6$ ), participated in group interviews, which were conducted outside in the village at places chosen by participants, usually next to a homestead.

We recorded all focus group discussions (totalling 217 mins) using detailed notes and a voice recorder for verification. We assigned initial codes to transcripts, used memos to review these codes (following Birks et al. 2008) and developed a final set of codes based on emergent themes (Stewart and Shamdasani 2014).

\subsection{Participant observation}

CP (first author) spent 13 months living in the SoumossoKoba-Larama area, and accompanied local women collecting and preparing caterpillars during two caterpillar seasons, in 2016 and 2017. Knowledge and experience gained during this time informed the structure of the study as a whole, and the design and analysis of the group interviews, particularly when writing questions and coding responses.

\subsection{Ethics}

All interview, survey and focus group protocols were developed in accordance with the Research Ethics Review Group, Department of Geography, University of Cambridge, which follows the Policy on the Ethics of Research developed by the University Ethics Committee (University Research Ethics Committee 2016).

\subsection{Statistical analyses}

All statistical analyses were performed in R. Non-normally distributed data (quantity of caterpillars collected, consumed and sold) were $\log _{10}$-transformed before analyses; consumption of dried caterpillars could not be log-transformed because of zero values so was instead analysed as a binary variable (consumed/not consumed). Where means and SDs are reported, these have been back-transformed.

\section{Results}

Caterpillars are collected in large quantities (median $=4.26 \mathrm{~kg}$ per person per season, range $=0-39 \mathrm{~kg}$, further details given in S1). Per season, women estimated that they had spent a mean of 15 days (range $=5-30, N=44$ ) and a median of $30 \mathrm{~h}$ $(\mathrm{IQR}=35)$ collecting caterpillars. The estimated season in Sitiena (mean $=12$ days, $N=19$ ) was significantly longer than in the Soumosso-Koba-Larama area (mean $=18$ days, $N=25$; Kruskal-Wallis rank sum test, $\left.\chi^{2}=10, p<0.005, \mathrm{df}=1\right)$.

\subsection{Nutritional contribution of caterpillars}

Prior to cooking, caterpillars are high in key nutrients: $100 \mathrm{~g}$ of fresh shea caterpillars: is $150 \%, 63.7 \%$ and $173 \%$ respectively of the recommended daily intake of protein, iron and zinc, respectively, for a woman of reproductive age (Table S1).

When cooked, the reported portion of a caterpillar dish contains a median of $395 \%(\mathrm{IQR}=145), 232 \%(\mathrm{IQR}=42.8)$ and $456 \%$ (IQR $=165$ ) of the recommended daily intake for 
Protein, Iron and Zinc (Fig. S1). Portions also contain high amounts of fat (median $=209 \%$ of recommended daily intake, $\mathrm{IQR}=102$ ), due to the oil used during the cooking process.

During caterpillar season - that is, the time period during which caterpillars can be collected in the area - respondents to HFIAS surveys $(N=57)$ reported eating caterpillars a median of 3 (range $=0-14$ ) times a week, but this fell to a median of 0 (range $=0-2$ ) times a week in the dry season when only dried caterpillars are available. Animal protein consumption differed significantly by protein type and by season (repeatedmeasures two-way ANOVA adjusted for between-subject random error, protein: $\mathrm{F}_{(2,280)}=9.23, p=0.001$; season: $\mathrm{F}_{(1,280)}=$ $41.31, p<0.001$; Fig. 3). A post-hoc Tukey test showed that while there was no difference in the frequency of fish $(p=1)$ or meat $(\mathrm{p}=1)$ consumption between seasons, there was a significant difference in caterpillar consumption $(\mathrm{p}<0.001)$ (Table S1). Therefore total animal protein consumption was higher in caterpillar season, due to the consumption of caterpillars (Fig. 3).

\subsection{Financial contribution of caterpillars}

Caterpillars are a major source of income: more caterpillars are sold per person per year (median $=3.33 \mathrm{~kg}, \mathrm{IQR}=$ $4.41 \mathrm{~kg}$ ) than consumed fresh (median $=0.263 \mathrm{~kg}, \mathrm{IQR}=$ $0.425 \mathrm{~kg}$ ) or dried (median $=0 \mathrm{~kg}, \mathrm{IQR}=2.1 \mathrm{~kg}$ ) (Fig. S2).

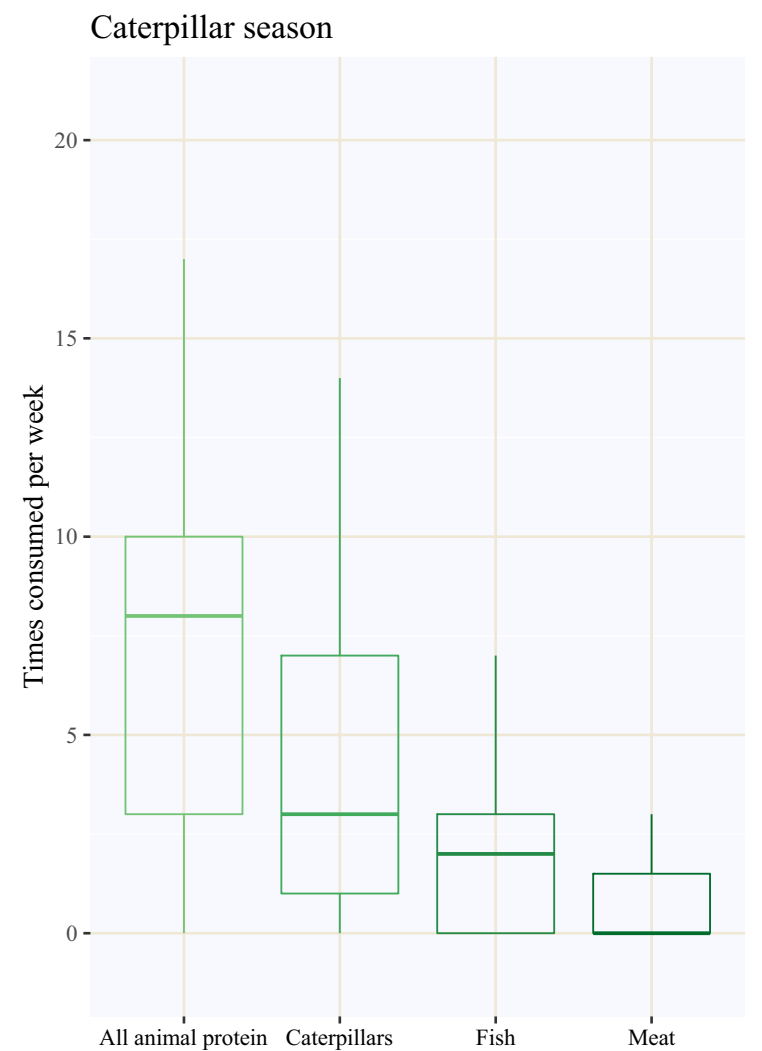

Reported household and per person income from caterpillars is equivalent to income from shea nuts; the same is true when this is adjusted to represent a proportion of overall household wealth (Fig. 4). Discussions in group interviews confirmed that women consider caterpillars and shea nuts to be their primary income sources (Fig. S3).

\subsection{Caterpillars and food security}

The majority of households experience some degree of food insecurity during both seasons, but food insecurity is significantly lower during caterpillar season. During the dry season, $28 \%$ of households in the caterpillar season and $52.6 \%$ of households are severely food insecure (HFIAS category $=4$ ); HFIAS scores are significantly lower during caterpillar season (paired Wilcoxon signed-rank test, $\mathrm{V}=384, N=57, p<0.05$, Fig. 5).

Higher food security during the caterpillar season is predicted by the amount of caterpillars sold and consumed. There is no collinearity between the sale and consumption of caterpillars (Kendall's tau $=0.33, \mathrm{z}=3.13$, following the 0.7 cutoff for collinearity advocated by Dormann et al. 2013), and both predict food security during the caterpillar season (Multiple linear regression, $\mathrm{F}_{2,17}=13.21, p<0.001$, Fig. 6): the more caterpillars consumed and sold, the higher the household's food security.

Dry season

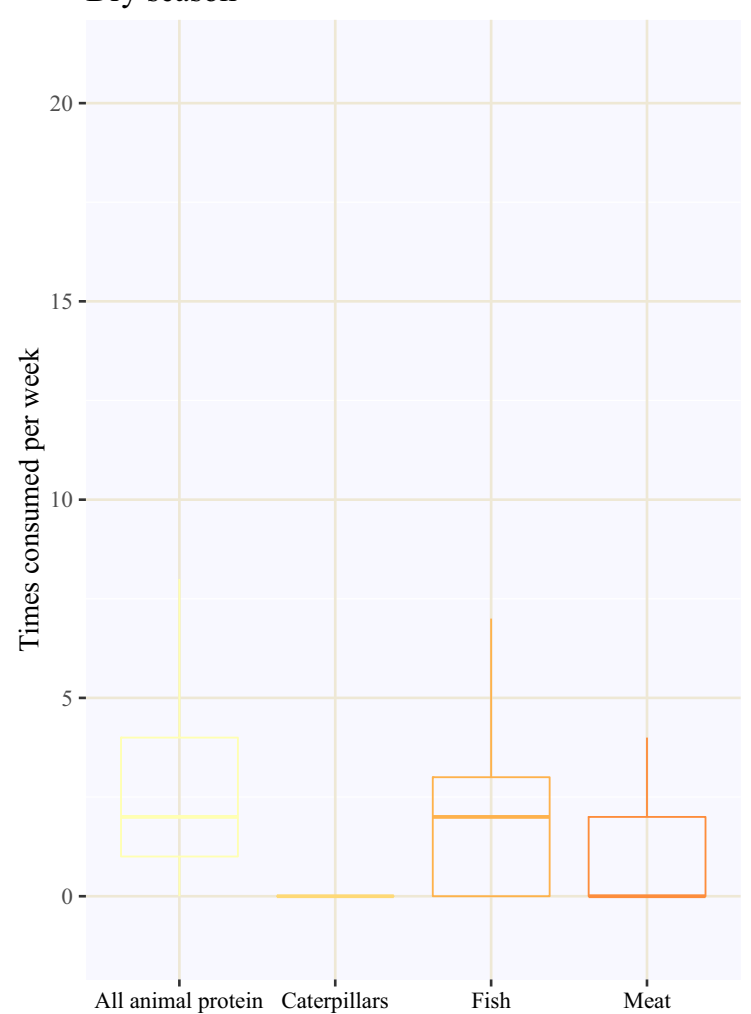

Fig. 3 The reported weekly consumption of animal protein sources during caterpillar season during the caterpillar season in late July (left) and during the dry season in March (right), according to responses $(N=49)$ to post-HFIAS survey questions 
Total household income

$200000-$

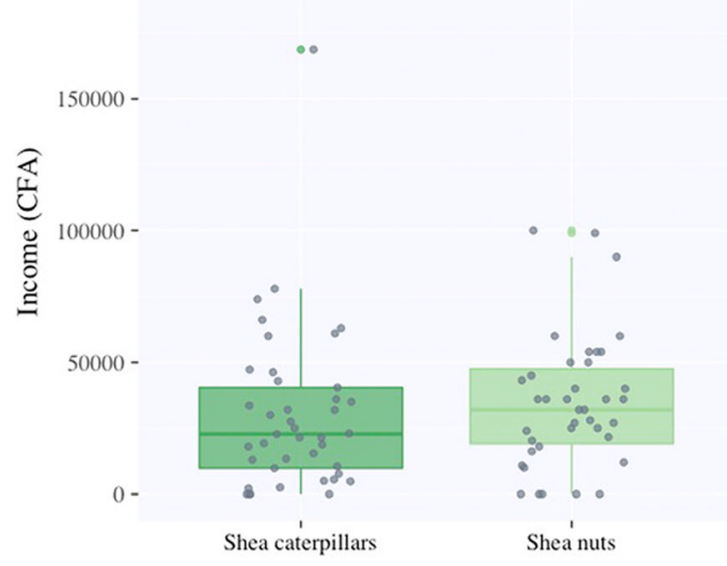

By household

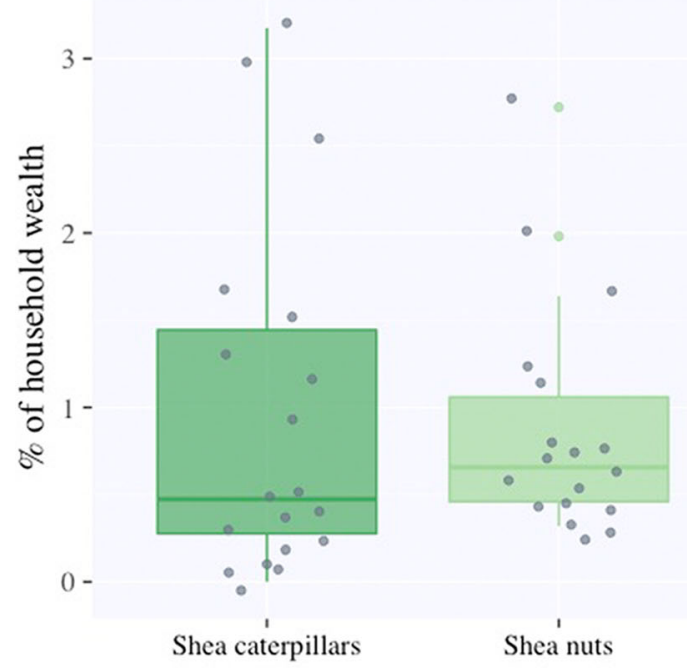

Fig. 4 Top row: Reported income obtained from shea caterpillars and from shea nuts, per household per year (Wilcoxon signed rank test, $\mathrm{V}=$ $282, N=36, \mathrm{NS})$ and per person per year $(\mathrm{V}=212, \mathrm{~N}=36$, NS, for income per person). Values are in CFA (African Financial Community), the local currency in Burkina Faso; 1CFA $=0.0017$ USD (as of 15.07.2018). All data represent responses to structured interviews ( $N=$ 45). Lower row: Reported income obtained from shea caterpillars and from shea nuts, per household (Wilcoxon rank sum test, $\mathrm{W}=143, \mathrm{~N}=$

Participants in group interviews all agreed that food security varies seasonally, and that without caterpillars they would be less food-secure overall. There was not a single focus group in which respondents did not discuss poverty and food scarcity, despite a lack of explicit prompting (Table 1).

However, this relationship did not hold when this season's caterpillar sale and consumption were compared with food security during the following dry season (Multiple linear regression, $\mathrm{F}_{2,36}=0.47, \mathrm{p}=\mathrm{NS}$ ). This suggests that greater caterpillar use in one season does not have effects on food security which carry over into the next year. It also suggests that the relationship shown in Fig. 6 is not due to more food secure
Per person income

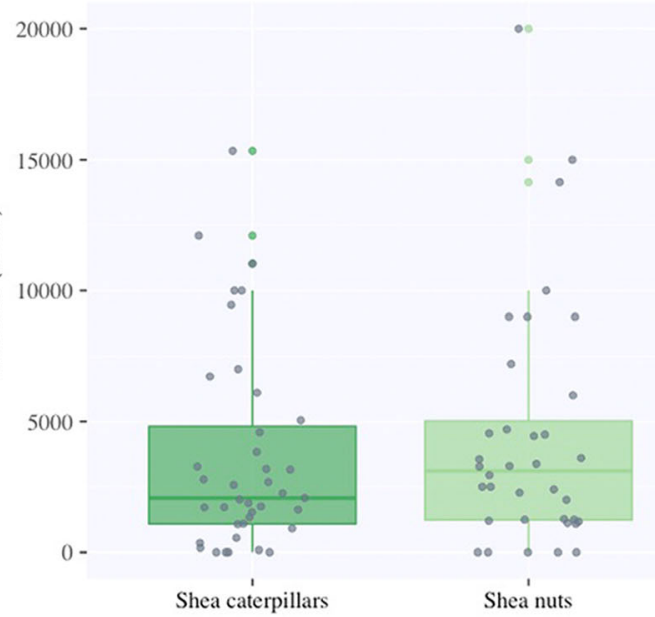

\section{By person}

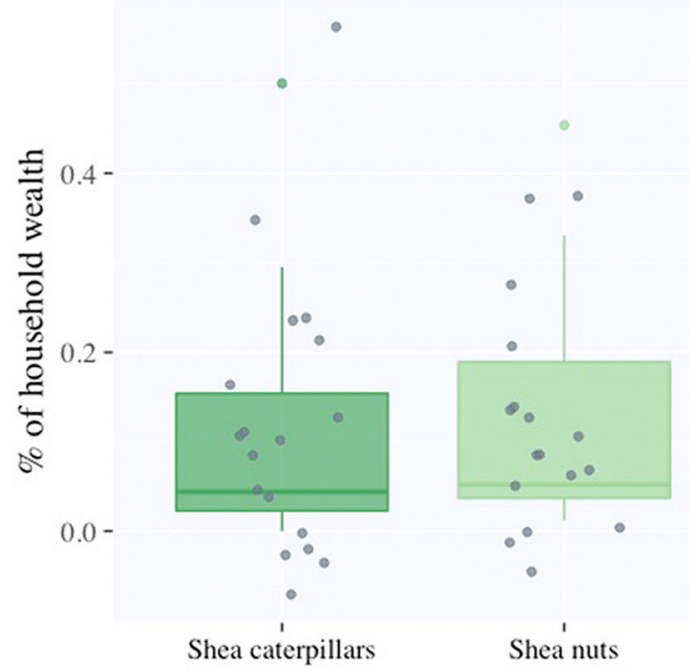

$36, \mathrm{NS}$ ) and per person (Wilcoxon rank sum test, $\mathrm{W}=132, \mathrm{~N}=36, \mathrm{NS}$ ), as a percentage of household wealth estimate. Plots show median and interquartile range; error bars show the largest and smallest values within 1.5 times the interquartile range above and below the 25th and 75 th percentiles respectively. We present all four graphs to show that no matter what measure is used, the evidence suggests that caterpillars represent an important contribution to income in this region

households having more time or ability to collect caterpillars, but instead that caterpillar consumption and sale directly increase short-term food security for households.

\subsubsection{Predictors of variation in caterpillar collection, consumption and sale}

During group interviews many respondents expressed a belief that some households, and people within households, collect more caterpillars than others, but reasons for this were diverse (Table 1). Youth and associated attributes such as strength and speed were common explanations for why some people 


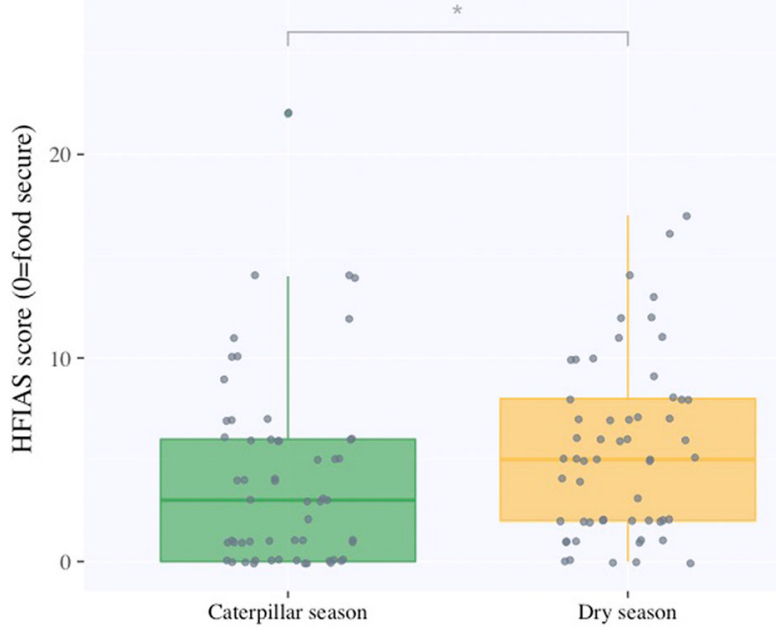

Fig. 5 Results of HFIAS surveys during and after caterpillar season. Higher HFIAS scores suggest higher food insecurity. HFIAS scores are significantly lower during caterpillar season (paired Wilcoxon signedrank test, $\mathrm{V}=384, \mathrm{~N}=57, \mathrm{p}<0.05$ ). Boxplots show the median and inter-quartile range for each season (median $=3$ during caterpillar season; 5 during the dry season. $\mathrm{IQR}=6$ during both seasons) collected more caterpillars. Ethnicity and gender were also cited as factors by a minority of respondents: they reported that individuals of Mossi ethnicity are early risers who collect many caterpillars to sell but do not eat them, and that men are faster collectors. Money from selling caterpillars is primarily used for food, but also to purchase items such as clothes, shoes, seeds and crockery.

Our analyses supported some of these observations (S4): Consumption of caterpillars was significantly associated with ethnicity and location (multiple linear regression, $\mathrm{R}^{2}=0.6$, $\left.\mathrm{F}_{11,31}=6.82, p<0.001\right)$. Mossi, Dioula and Dafi-headed households consumed more caterpillars. The ethnicity of the first wife of the male head of household was also a predictor of caterpillar consumption: households headed by women of Peul or Bwoba ethnicity consumed more caterpillars. Households located in Soumosso consumed fewer caterpillars than those located in Sitiena. There was no significant relationship between estimated household wealth and caterpillar consumption. These associations did not hold for the sale of caterpillars: the amount of caterpillars sold was not significantly associated with ethnicity, location or household wealth (multiple linear regression, $\mathrm{R}^{2}=$ $0.097, \mathrm{~F}_{11,31}=0.66, \mathrm{p}=\mathrm{NS}$ ).

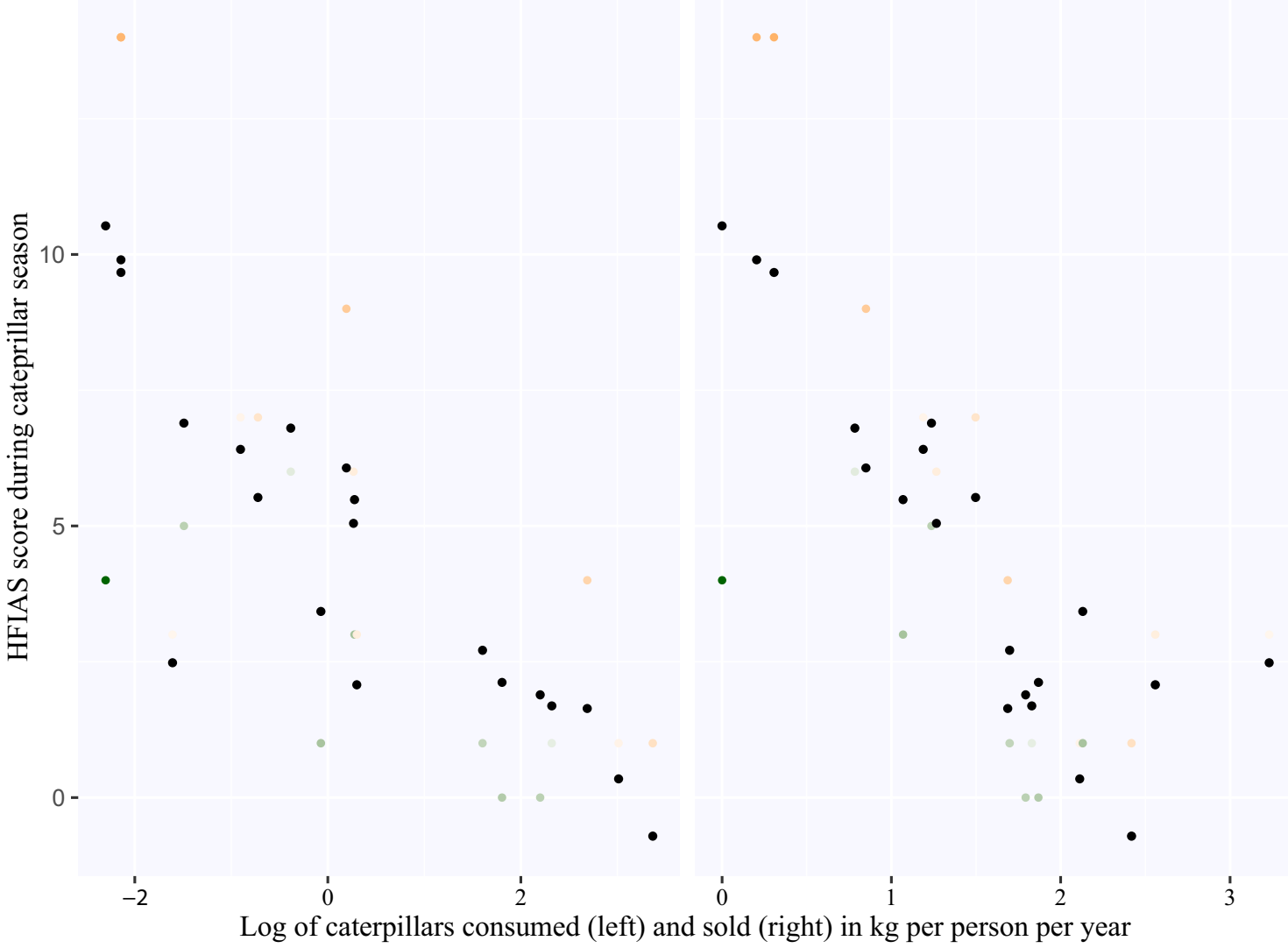

Fig. 6 HFIAS scores (actual values are coloured, predicted values are in black) during the caterpillar season and caterpillars consumed (left) and sold (right). Actual values are in orange if higher than predicted values; in green if lower than predicted values. Transparency of actual values reflects residuals: high transparency indicates a low residual value, a more solid colour indicates a high residual value. Caterpillars consumed and sold are kg per person per year, log transformed. A lower HFIAS score implies higher reported food security 


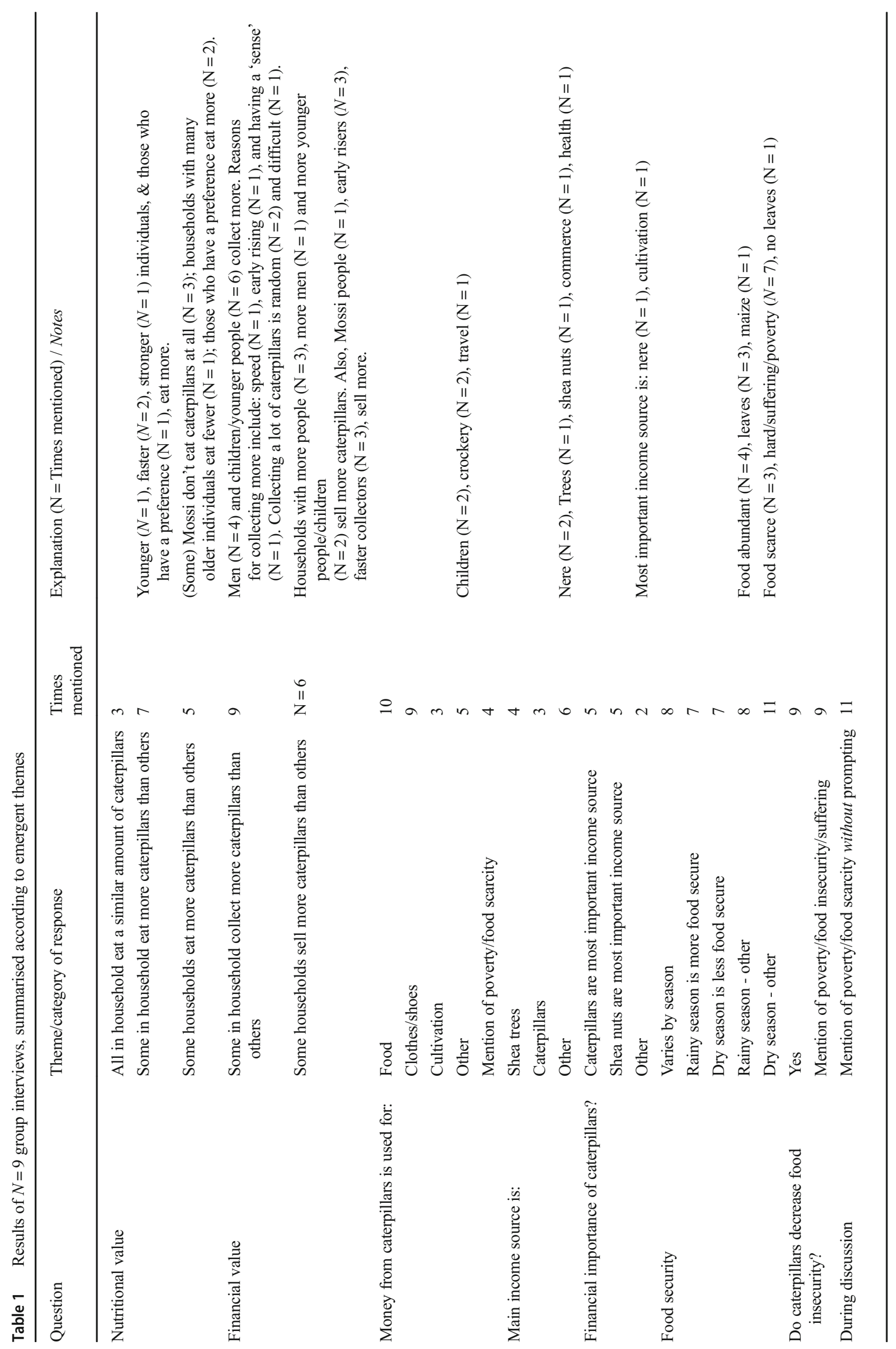




\subsubsection{Ethnicity and caterpillar collection}

Interview data shows that households in which the male head of household was of Dioula ethnicity consumed more fresh caterpillars than people of Mossi ethnicity, but the same was not true for female heads of household. Dioula people have a long tradition of eating caterpillars, while the Mossi population in the area are largely migrants from areas without caterpillars. In group interviews, some respondents raised concerns about how Mossi collecting practices (collecting very early in the morning and selling rather than eating the caterpillars) might negatively influence both the sustainability of the caterpillar population and the benefits the non-Mossi people are able to accrue from the caterpillars.

\section{Discussion}

Edible insects are receiving increasing attention for their posited role in current and future food security (Van Huis et al. 2013; Van Huis 2015), but data on the present contribution of edible insects to household level food security in food-insecure regions are sparse (Kelemu et al. 2015, but see Baiyegunhi et al. 2016). We therefore used a mixed methods approach to assess who currently benefits from the harvest of shea caterpillars in southwestern Burkina Faso, what those benefits constitute, and how this impacts the overall food security status of households at risk. We found that food security is significantly higher during the caterpillar season. Households that collected, consumed and sold more caterpillars were those that were more food-secure, suggesting that the association between caterpillars and higher food security may be a causal relationship. We found that the relationship did not persist out of caterpillar season, suggesting that caterpillar collection directly enhances immediate food security.

This contribution to food security appears to be driven by two key elements, both recognised as important in conferring food security. The first of these is the provision of a higher quality diet: caterpillars are a nutrient-rich source of animal protein, and their seasonal consumption increases overall levels of animal protein in diets of smallholders in this region. The second is through the provision of income: women reported a high income contribution from caterpillars, and emphasised the financial benefits of caterpillar season. Thus, the caterpillars improve food security in a way that is both directly 'food-based' (Burchi et al. 2011) yet also improves livelihoods (Garibaldi et al. 2017). Further research may consider whether or not the collection, consumption and sale of caterpillars also improves self-perceptions of food sovereignty (Weiler et al. 2014) and empowerment (Conceição et al. 2016). Policymakers should consider how this can be leveraged to further improve food security, perhaps through the funding of cooperatives and developing processing methods that add value, strategies that have been used in the region to improve food security using shea (Sidibé et al. 2014).
The link between edible insects and food security has been discussed widely. In areas where people have market access, edible insects contribute to food security via both nutrition and income (Van Huis et al. 2013; Kelemu et al. 2015). This has been shown to be the case in South Africa, where Baiyegunhi et al. (2016) found that income from, and consumption of, the mopane caterpillar Gonimbrasia belina was positively associated with food security. However, this is the first study to our knowledge that has investigated the seasonality of insects' contribution to food security. We found that the collection and consumption of a seasonal edible insect does not confer greater food security on families throughout the year; policymakers should take this into account when developing strategies to combat food insecurity using edible insects.

We found that shea caterpillars were an important source of nutrition for many households. During caterpillar season, caterpillars were consumed more frequently than other sources of animal protein and the total frequency of animal protein consumption rose significantly as a result. Reported serving sizes suggest that caterpillars are eaten in large quantities, in dishes high in protein, fat, iron and zinc. This is particularly important given that protein malnutrition and anaemia are known to be common in rural West Africa (Schulte-Herbrüggen et al. 2017; Petry et al. 2016).

Caterpillars also provide a significant source of income for people in this region; most women reported that caterpillars or the combination of caterpillars and shea nuts were their most significant income source on an annual basis. In absolute terms and when proportional to household income, annual income from caterpillars was similar to that from shea nuts. When expressed as a proportion of overall household wealth the contribution of both caterpillars and shea is low; this may be because most wealth is held in assets rather than earned on an annual basis. Income from caterpillars is primarily spent on food, but also on other personal and household essentials.

Therefore, shea caterpillars may offer temporary alleviation of both malnutrition and poverty, both of which are prevalent in this region (Akombi et al. 2017). However, this study does not measure the bioavailability of nutrients for people consuming caterpillars, nor the immediate health implications of caterpillar consumption. Populations in this area would benefit greatly from research into confounding factors that may limit the nutritional potential of the caterpillars, such as different methods of preparation.

Previous research has highlighted the importance of shea nuts for women's livelihoods (Poole et al. 2016; Audia et al. 2015; Beczner et al. 2017); it is notable that in this area caterpillars are on a par with shea nuts in terms of income generation. This may mean that regions with caterpillars suffer less from poverty than those without caterpillars. However, caterpillar collection is tiring and time consuming, so there may also be trade-offs in the amount of energy used to collect caterpillars and energy needed to collect and process shea 
and other food crops. Furthermore, variation in climate and market price is known to impact household income and food security in this region (Wossen et al. 2017). This study took place over a short time period and does not take into account fluctuations in market prices of shea nuts or caterpillars, and how this may impact collection patterns and the relationship between caterpillars and food security; policymakers would benefit from future research that also looks at these external influences.

Finally, we found that consumption of caterpillars varies between households. The amount of caterpillars sold was not predicted by ethnicity, location, or household wealth (see S4), but the amount of caterpillars consumed varied by ethnicity and location. Importantly, the intersection between gender and ethnicity predicted caterpillar consumption to some extent. This data suggests that ethnic background influences caterpillar consumption but that women may be more likely to adapt their caterpillar consumption and preparation to their husband's tastes, rather than vice versa Concerns about Mossi households overharvesting were not common, but may be important: these results suggest that a minority of people experience underlying tensions based on ethnicity and migrant status. It is crucial that policymakers and future researchers working in this area take this into account.

\section{Conclusion}

In this study, we report evidence that the collection, consumption and sale of edible caterpillars make a significant positive contribution to household-level food security on a seasonal basis in rural southwestern Burkina Faso. Edible insects have been advocated as potentially important to global food security; this study both exposes their limitations in terms of seasonality and emphasises their dual importance as a source of both income and nutrition. In this study we do not investigate the health implications of insect consumption, nor do we compare communities that harvest insects with those that do not. The study took place over two years (and two caterpillar seasons), which is too short a time period to consider the likely impacts of temporal variation in climate and market price. We recommend that future research considers these longer-term variables, and looks more closely at the relationship between insect consumption and health outcomes. We conclude that shea caterpillars in southwestern Burkina Faso are an example of an edible insect that is an important part of a widespread agricultural system, and that without the presence of caterpillars seasonal malnutrition and poverty would likely intensify.

Acknowledgements We would like to thank Baly Ouattara, Kahit Hien and Poda Nambepierre for providing field support and facilitation, making this study possible. We thank our field assistants Momoni Ouattara, Baya Ouattara, Sanou Afsietta, Bertine Some and Flora Some for their assistance with data collection. We also thank the Natural Environment Research Council of the UK (NERC), the Barilla Center for Food and
Nutrition (BCFN), King's College, Cambridge, and the Department of Zoology at the University of Cambridge, for financial support.

\section{Compliance with ethical standards}

Conflict of interest All authors declared that they have no conflict of interest.

Open Access This article is distributed under the terms of the Creative Commons Attribution 4.0 International License (http:// creativecommons.org/licenses/by/4.0/), which permits unrestricted use, distribution, and reproduction in any medium, provided you give appropriate credit to the original author(s) and the source, provide a link to the Creative Commons license, and indicate if changes were made.

\section{References}

Agbidye, F. S., Ofuya, T. I., \& Akindele, S. O. (2009). Some edible insect species consumed by the people of Benue State, Nigeria. Pakistan Journal of Nutrition, 8(7), 946-950.

Akombi, B. J., Agho, K. E., Merom, D., Renzaho, A. M., \& Hall, J. J. (2017). Child malnutrition in sub-Saharan Africa: A meta-analysis of demographic and health surveys (2006-2016). PLoS One, 12(5), e0177338.

Anankware, J. P., Osekre, E. A., Obeng-Ofori, D., \& Khamala, C. (2016). Identification and classification of common edible insects in Ghana. International Journal of Entomology Research, 1(5), 33-39.

Anvo, M. P. M., Toguyéni, A., Otchoumou, A. K., Zoungrana-Kaboré, C. Y., \& Kouamelan, E. P. (2016). Nutritional qualities of edible caterpillars Cirina butyrospermi in southwestern of Burkina Faso. International Journal of Innovation and Applied Studies, 18(2), 639.

Anvo, M. P. M., Aboua, B. R. D., Compaoré, I., Sissao, R., ZoungranaKaboré, C. Y., Kouamelan, E. P., \& Toguyéni, A. (2017). Fish meal replacement by Cirina butyrospermi caterpillar's meal in practical diets for Clarias gariepinus fingerlings. Aquaculture Research, 48, 5243-5250.

Audia, C., Kaboret, B., Kent, R., Hill, T., \& Poole, N. (2015). The contribution of tree crop products to smallholder households: A case study of baobab, shea, and néré in Burkina Faso. FAO Commodity and Trade Policy Research Working Papers, 49, III.

Baiyegunhi, L. J. S., Oppong, B. B., \& Senyolo, G. M. (2016). Mopane worm (Imbrasia belina) and rural household food security in Limpopo province, South Africa. Food Security, 8(1), 153-165.

Bama, H. B., Dabire, R. A., Ouattara, D., Niassy, S., Ba, M. N., \& Dakouo, D. (2018). Diapause disruption in Cirina butyrospermi Vuillet (Lepidoptera, Attacidae), the shea caterpillar, in Burkina Faso. Journal of Insects as Food and Feed, 4, 239-245.

Banjo, A. D., Lawal, O. A., \& Songonuga, E. A. (2006). The nutritional value of fourteen species of edible insects in southwestern Nigeria. African Journal of Biotechnology, 5(3), 298-301.

Beczner, C., Gower, B., \& Vizzoni, P. (2017). Women's gold. In Corporate citizenship in Africa: Lessons from the past; Paths to the future Routledge (Abingdon, Oxon, UK) (p. 224).

Birks, M., Chapman, Y., \& Francis, K. (2008). Memoing in qualitative research: Probing data and processes. Journal of Research in Nursing, 13(1), 68-75.

Biro, G., Hulshof, K. F., Ovesen, L., \& Amorim Cruz, J. A. (2002). Selection of methodology to assess food intake. European Journal of Clinical Nutrition, 56(suppl. 2), S25-S32.

Burchi, F., Fanzo, J., \& Frison, E. (2011). The role of food and nutrition system approaches in tackling hidden hunger. International Journal of Environmental Research and Public Health, 8(2), 358-373. 
Charrondiere, U.R., Haytowitz, D.B., Stadlmayr, B., 2012a. FAO/ INFOODS density database, version 2.0. Food and Agriculture Organization of the United Nations Technical Workshop Report

Charrondiere U.R., Enujiugha V.N., Bayili R.G. and Fagbohoun, E.G., 2012b. West African food composition table. Food and Agriculture Organization of the United Nations

Coates, J., Swindale, A., \& Bilinsky, P. (2007). Household food insecurity access scale (HFIAS) for measurement of household food access: Indicator guide (Vol. 3). Washington, DC: Food and Nutrition Technical Assistance Project, Academy for Educational Development. Available online: http://www.fao.org/fileadmin/ user_upload/eufao-fsi4dm/doc-training/hfias.pdf.

Conceição, P., Levine, S., Lipton, M., \& Warren-Rodríguez, A. (2016). Toward a food secure future: Ensuring food security for sustainable human development in sub-Saharan Africa. Food Policy, 60, 1-9.

Cox, S. M., Payne, C., Badolo, A., Attenborough, R., \& Milbank, C. (2018). The nutritional role of insects as food: A case study of 'chitoumou' (Cirina butyrospermi), an edible caterpillar in rural Burkina Faso. Journal of Insects as Food and Feed.https://www. wageningenacademic.com/doi/abs/10.3920/JIFF2018.0030 Accessed 21 Dec 2018

Creswell, J. W., \& Clark, V. L. P. (2007). Designing and conducting mixed methods research. Thousand Oaks, CA: SAGE Publications, Inc.

Dormann, C. F., Elith, J., Bacher, S., Buchmann, C., Carl, G., Carré, G., et al. (2013). Collinearity: A review of methods to deal with it and a simulation study evaluating their performance. Ecography, 36(1), 27-46.

Douxchamps, S., Van Wijk, M. T., Silvestri, S., Moussa, A. S., Quiros, C., Ndour, N. Y. B., Buah, S., Somé, L., Herrero, M., Kristjanson, P., \& Ouedraogo, M. (2016). Linking agricultural adaptation strategies, food security and vulnerability: Evidence from West Africa. Regional Environmental Change, 16(5), 1305-1317.

FAO. (2015). The state of food security in the world. Rome: Food and Agriculture Organization of the United Nations. Available online: $\mathrm{http}: / /$ www.fao.org/3/a-i4646e.pdf.

Garibaldi, L. A., Gemmill-Herren, B., D'Annolfo, R., Graeub, B. E., Cunningham, S. A., \& Breeze, T. D. (2017). Farming approaches for greater biodiversity, livelihoods, and food security. Trends in Ecology \& Evolution, 32(1), 68-80.

Green, J., \& Thorogood, N. (2014). Qualitative methods for health research. Los Angeles, CA: SAGE Publications, Inc..

Greffeuille, V., Mouquet-Rivier, C., Icard Vernière, C., Laurencia, O., Hounhouigan, D., Waliou, A., Kayodé, P., Fatoumata, H. 2010. Traditional recipes of millet, sorghum, and maize-based dishes and related sauces frequently consumed by young children in Burkina Faso and Benin. INSTAPA, ISBN 978-90-8585-903-3.

Heckathorn, D. D. (2011). Comment: Snowball versus respondent-driven sampling. Sociological Methodology, 41(1), 355-366.

Huybregts, L. F., Roberfroid, D. A., Kolsteren, P. W., \& Van Camp, J. H. (2009). Dietary behaviour, food and nutrient intake of pregnant women in a rural community in Burkina Faso. Maternal \& Child Nutrition, 5, 211-222.

International Food Policy (IFP). (2014). Global hunger index: The challenge of hidden hunger. Washington/Dublin: International Food Policy Research Institute. Available online: https://www. concernusa.org/content/uploads/2015/03/2014GHI.pdf.

Jones, A. D., Ngure, F. M., Pelto, G., \& Young, S. L. (2013). What are we assessing when we measure food security? A compendium and review of current metrics. Advances in Nutrition, 4(5), 481-505.

Kaiser, L., Chaidez, V., Algert, S., Horowitz, M., Martin, A., Mendoza, C., Neelon, M., \& Ginsburg, D. C. (2015). Food resource management education with SNAP participation improves food security. Journal of Nutrition Education and Behavior, 47(4), 374-378.

Kelemu, S., Niassy, S., Torto, B., Fiaboe, K., Affognon, H., Tonnang, H., Maniania, N. K., \& Ekesi, S. (2015). African edible insects for food and feed: Inventory, diversity, commonalities and contribution to food security. Journal of Insects as Food and Feed, 1(2), 103-119.
Malaisse, F., Mabossy-Mobouna, G., \& Latham, P. (2017). Un Atlas des chenilles et chrysalides consommées en Afrique par l'homme (An Atlas of caterpillars and chrysalises consumed by man in Africa). Geo-Eco-Trop, 41, 55-66.

Manditsera, F. A., Luning, P. A., Fogliano, V., \& Lakemond, C. M. (2019). The contribution of wild harvested edible insects (Eulepida mashona and Henicus whellani) to nutrition security in Zimbabwe. Journal of Food Composition and Analysis, 75, 17-25.

Naughton, C. C., Lovett, P. N., \& Mihelcic, J. R. (2015). Land suitability modeling of shea (Vitellaria paradoxa) distribution across subSaharan Africa. Applied Geography, 58, 217-227.

Nordeide, M. B., Hatløy, A., Følling, M., Lied, E., \& Oshaug, A. (1996). Nutrient composition and nutritional importance of green leaves and wild food resources in an agricultural district, Koutiala, in southern Mali. International Journal of Food Sciences and Nutrition, 47(6), 455-468.

Payne, C. L., \& Van Itterbeeck, J. (2017). Ecosystem services from edible insects in agricultural systems: A review. Insects, 8(1), 24.

Payne, C. L., Umemura, M., Dube, S., Azuma, A., Takenaka, C., \& Nonaka, K. (2015). The mineral composition of five insects as sold for human consumption in southern Africa. African Journal of Biotechnology, 14(31), 2443-2448.

Petry, N., Olofin, I., Hurrell, R. F., Boy, E., Wirth, J. P., Moursi, M., Donahue Angel, M., \& Rohner, F. (2016). The proportion of anemia associated with iron deficiency in low, medium, and high human development index countries: A systematic analysis of national surveys. Nutrients, 8(11), 693.

Poole, N., Audia, C., Kaboret, B., \& Kent, R. (2016). Tree products, food security and livelihoods: A household study of Burkina Faso. Environmental Conservation, 43(4), 359-367.

Porter, J.R., Xie, L., Challinor, A.J., Cochrane, K., Howden, S.M., Iqbal, M.M., Lobell, D.B., Travasso, M.I., Netra Chhetri, N.C., Garrett, K. and Ingram, J., 2014. Food security and food production systems.

Rémy, D. A., Hervé, B. B., \& Sylvain, O. N. (2017). Study of some biological parameters of Cirina butyrospermi Vuillet (Lepidoptera, Attacidae), an edible insect and shea caterpillar (Butyrospermum paradoxum Gaertn. F.) in a context of climate change in Burkina Faso. Advances in Entomology, 6(1), 1-8.

Ritzema, R. S., Frelat, R., Douxchamps, S., Silvestri, S., Rufino, M. C., Herrero, M., Giller, K. E., López-Ridaura, S., Teufel, N., Paul, B. K., \& Van Wijk, M. T. (2017). Is production intensification likely to make farm households food-adequate? A simple food availability analysis across smallholder farming systems from East and West Africa. Food Security, 9(1), 115-131.

Samberg, L. H., Gerber, J. S., Ramankutty, N., Herrero, M., \& West, P. C. (2016). Subnational distribution of average farm size and smallholder contributions to global food production. Environmental Research Letters, 11(12), 124010.

Schulte-Herbrüggen, B., Cowlishaw, G., Homewood, K., \& Rowcliffe, J. M. (2017). Rural protein insufficiency in a wildlife-depleted West African farm-forest landscape. PLoS One, 12(12), e0188109.

Semba, R. D. (2016). The rise and fall of protein malnutrition in global health. Annals of Nutrition and Metabolism, 69(2), 79-88.

Sibhatu, K. T., \& Qaim, M. (2017). Rural food security, subsistence agriculture, and seasonality. PLoS One, 12(10), e0186406.

Sidibé, A., Vellema, S., Dembélé, F., Témé, B., Yossi, H., Traoré, M., \& Kuyper, T. W. (2014). Women, shea, and finance: How institutional practices in a Malian cooperative create development impact. International Journal of Agricultural Sustainability, 12(3), 263-275.

Stadlmayr, B., Wijesinha-Bettoni, R., Haytowitz, D., Rittenschober, D., Cunningham, J., Sobolewski, R., Eisenwagen, S., Baines, J., Probst, Y., Fitt, E., \& Charrondiere, U. R. (2011). INFOODS guidelines for food matching version 1.1. Rome: FAO/INFOODS.

Stewart, D. W., \& Shamdasani, P. N. (2014). Focus groups: Theory and practice (Vol. 20). Los Angeles: Sage Publications.

Tchibozo, S., Van Huis, A., \& Paoletti, M. G. (2005). Notes on edible insects of South Benin: A source of protein. In Ecological implications of 
Minilivestock. Role of rodents, frogs, snails and insects for sustainable development (pp. 246-250). Enfield: Science Publishers.

Timmer, C. P. (2005). Food security and economic growth: An Asian perspective. Asian-Pacific Economic Literature, 19(1), 1-17.

University Research Ethics Committee, 2016. University of Cambridge policy on the ethics of research involving human participants and personal data. Available online: https://www.research-integrity. admin.cam.ac.uk/files/policy on the ethics of research involving human participants_and_personal_data_oct_2016.pdf

Van Huis, A. (2015). Edible insects contributing to food security? Agriculture \& Food Security, 4(1), 20.

Van Huis, A., et al. (2013). Future prospects for food and feed security. Forestry Paper, 171 pp 187.

Weiler, A. M., Hergesheimer, C., Brisbois, B., Wittman, H., Yassi, A., \& Spiegel, J. M. (2014). Food sovereignty, food security and health equity: A meta-narrative mapping exercise. Health Policy and Planning, 30(8), 1078-1092.

World Health Organization (WHO). (2018). The state of food security and nutrition in the world 2018: Building climate resilience for food security and nutrition. Food \& Agriculture Org.

Wossen, T., Berger, T., Haile, M. G., \& Troost, C. (2017). Impacts of climate variability and food price volatility on household income and food security of farm households in East and West Africa. Agricultural Systems vol. 163(C), pp 7-15.

Wrieden W., Peace H, Armstrong J et al., 2003. A short review of dietary assessment methods used in national and scottish research studies. http://www.food.gov.uk/multimedia/pdfs/scotdietassessmethods. pdf [Accessed 25 April 2018].

Yen, A. L. (2015). Conservation of Lepidoptera used as human food and medicine. Current Opinion in Insect Science, 12, 102-108.

Zhao, F., McGrath, S. P., \& Crosland, A. R. (1994). Comparison of three wet digestion methods for the determination of plant sulphur by inductively coupled plasma atomic emission spectroscopy (ICPAES). Communications in soil science and plant analysis, 25(3-4), 407-418.

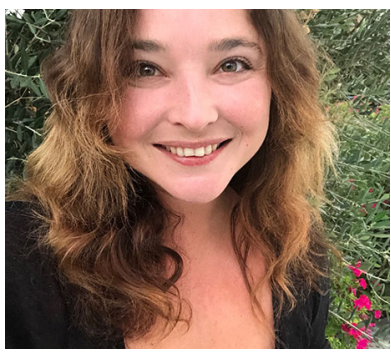

Charlotte Payne is a $\mathrm{PhD}$ candidate in the Department of Zoology, University of Cambridge, UK. She has worked on interdisciplinary research projects looking at insects eaten by humans and apes since 2008 , and has conducted fieldwork on this topic in Uganda, Democratic Republic of Congo, Japan, Zimbabwe, Mexico, Madagascar and Burkina Faso. She is part of IPSIO (Insects and People of the South Indian Ocean) and EntoTrust.

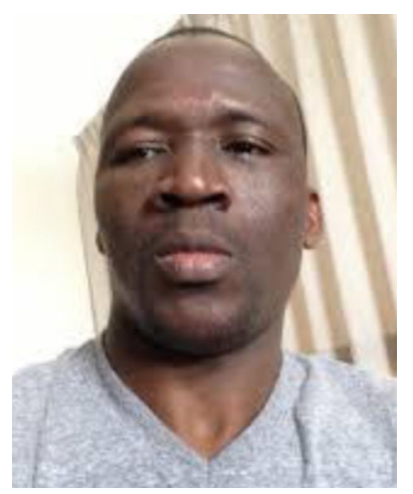

Athanase Badolo is a Biologist with a $\mathrm{PhD}$ in Entomology from Université Ouaga $1 \mathrm{JKZ}$. He is associate Professor at the Laboratory of Fundamental and applied Entomology, UO $1 \mathrm{JKZ}$, Department of Animal Biology and Ecology. Dr. Badolo special focus is mosquitoes vectors of diseases and insects as food to fight malnutrition and contribute to food sovereignty in Burkina Faso and elsewhere in Africa.

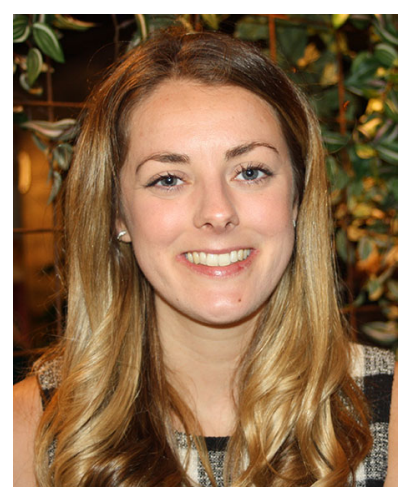

Sioned Cox received a bachelor's degree in Human, Social, Political Sciences, specialising in Biological Anthropology, from the University of Cambridge in 2018. For her final year dissertation project, she conducted research on the nutritional role of insects as food in southwestern Burkina Faso, now published online in the Journal of Insects as Food and Feed.

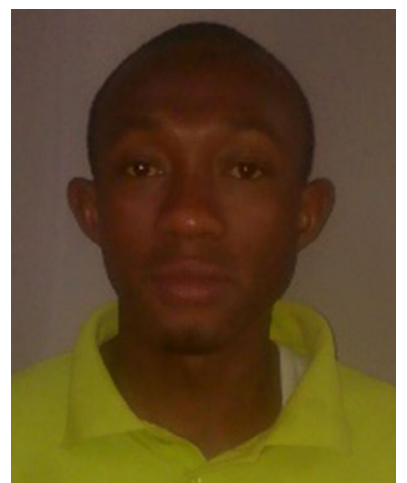

Bakary Sagnon graduated in Master of Entomology from Université Ouaga 1. For his Master, he worked on Cirina butyrospermi, the shea tree caterpillar. His Master's dissertation was entitled: "Impact of birds and arthropods abundance and diversity on Cirina butyrospermi caterpillars in two localities of western Burkina Faso". He is now looking for opportunities to do a $\mathrm{PhD}$ in the field of edible insects.

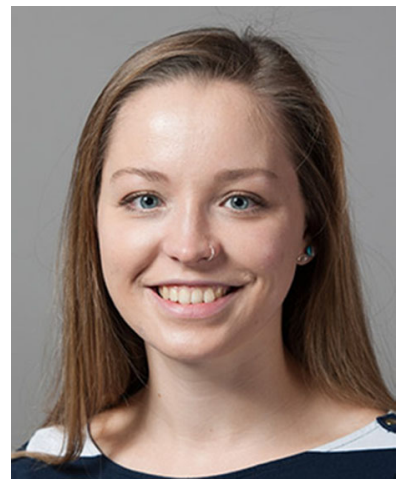

Darja Dobermann works at the intersection of her key research interests: maternal and child nutrition, malnutrition interventions, entomophagy and low-input sustainable aquaculture. She is examining nutritional levels of black crickets (gryllus bimaculatus) and black soldier fly larvae (Hermetia illucens) as food and feed. Trials with crickets aim to improve their survival on bio-wastes; trials with black soldier fly larvae are looking at their use to reduce manure waste and to improve traditional low-input fish feed. Darja also works on a joint project, with Charlotte Payne at the University of Cambridge and funded by the Barilla Centre for Food and Nutrition. This project aims to develop a way of breeding shea caterpillars (cirina butryospermi) domestically; the caterpillars are a prized food source in Burkina Faso. Before starting these PhD studies, Darja completed an MSc in Research Sociology (Distinction) at the University of Edinburgh and a BA in Psychology (Honours with Distinction) at the University of Victoria. Her experience in social sciences provides keen insight into how best to implement interventions within local communities. Darja is also a director of the Woven Network CIC, a UK community interest company that aims to support businesses and academics working on insects for food and feed. 


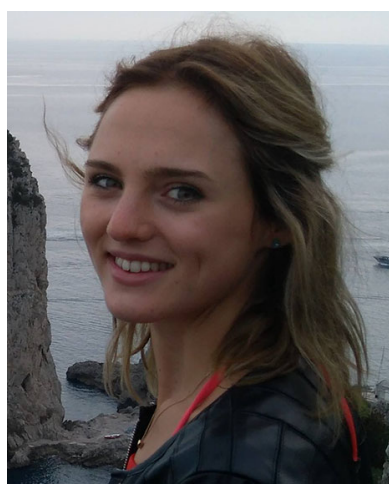

Charlotte Milbank is an MPhil candidate in Epidemiology at the University of Cambridge. She will commence her $\mathrm{PhD}$ in the Department of Geography in October 2019, specialising in malnutrition and uncultivated food use in forest-dependent communities. Charlotte has previously conducted fieldwork in Burkina Faso, Morocco and Kenya.

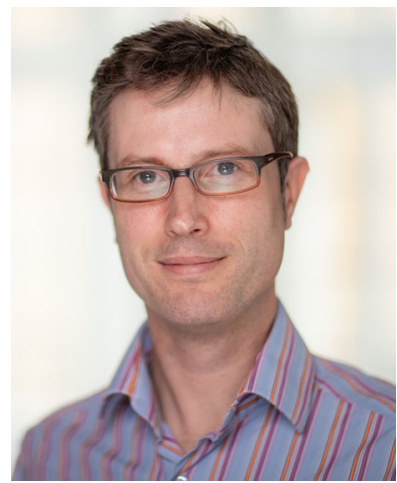

Peter Scarborough specialises in evaluating public health policies, sustainability of food systems and non-communicable disease scenario modelling. He has a background in mathematics and has worked in the Centre on Population Approaches for NonCommunicable Disease Prevention for over 15 years.

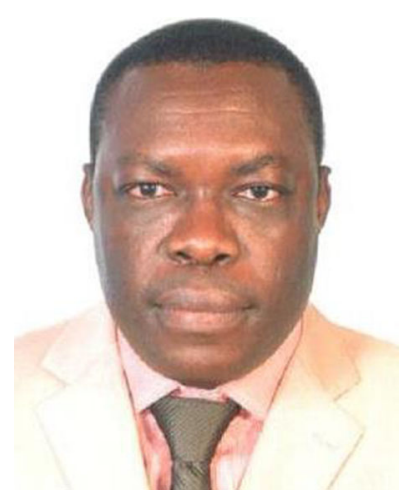

Antoine Sanon Professor, $\mathrm{PhD}$ Entomology. Head of entomology laboratory working for the University Ouaga I Pr Joseph KI-ZERBO. Coordinating research and $\mathrm{PhD}$ programs in all fields of entomology, including mainly agricultural and medical entomology and emerging fields of insect research as entomophagy.

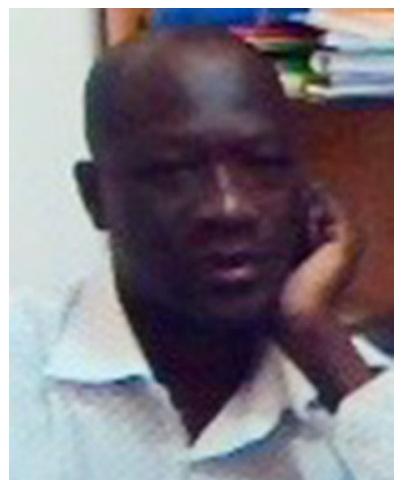

Bouma Fernand Bationo is a medical sociologist with a $\mathrm{PhD}$ in Social science and development from University Lille I (French). He is associate Professor at the Laboratory of interdisciplinary research in social science and Heath, UO1 Pr JKZ. B Fernand Bationo's special focus is maternal and infant health, vulnerability and social protection in Burkina Faso and elsewhere in West Africa.

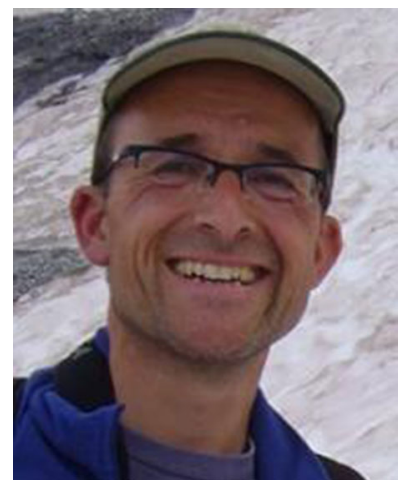

Andrew Balmford Andrew 's research focuses on the costs and benefits of conservation, how best to reconcile conservation and farming, the reasons why nature is being lost, and examining what works in conservation. He tackles these issues through fieldwork, analyses of large databases, and modeling, and by working wherever possible with colleagues in other disciplines and with conservation practitioners. He cofounded the Cambridge Conservation Forum; is closely involved in the Cambridge Conservation Initiative; and with Rhys Green, Rosie Trevelyan, Ed Turner and Shireen Green runs the annual Student Conference on Conservation Science. Andrew Balmford is also an Affiliate of the Gund Institute for Ecological Economics, University of Vermont, USA 